\title{
THE INFLUENCE OF RELIGIOSITY, INCOME AND CONSUMPTION ON SAVING BEHAVIOUR: The Case of International Islamic University Malaysia (Iium)
}

\author{
Naziruddin Abdullah \\ M. Shabri Abd. Majid
}

\begin{abstract}
Islam encourages its ummah to consume goods and services moderately, and prohibits them from wastage or extravagance. With these encouragements and prohibitions firmly embedded in the teachings of Islam, it is expected that the Muslims will save more out of their given income. Further, the limitation of consumption basket within the Islamic concept of permissibility (halal) and prohibition (haram), the potentiality of saving amongst the Muslims is obviously enhanced. This will in turn imply that a practising Muslim (i.e., the Muttaqin) who obeys all the shari'ah injunctions will tend to save more than the ignorant Muslims, cateris paribus. With this in mind, the paper attempts to measure the influence of religiosity, income and consumption on saving behaviour. To make the study materializes, the IIUM students, Malaysian and international, are taken as the case study. From the empirical results, it is found that the religiosity and other variables have a significant impact on the IIUM students' saving behaviour. The inference of the finding is that such a relationship, for example, between religiosity and saving may exist if the study is extended to investigate the saving behaviour of Muslims with different credentials.
\end{abstract}

Key words: Saving behaviour, Religiosity, Consumption and Income.

\section{INTRODUCTION}

Islam is a way of life (Nizam al-hayah). It is not the acts of worship that makes up the religion but also the entire economic, social and political systems. In fact, any activities done, as long as within the divinely prescribed framework, are treated as part and parcel of Islam. Thus, a compartmentalization of the religion into smaller components such as worldly (human action) and non-worldly (divine action) is nothing but a fabricated product of a secularist with biformity or duplexity mentality.

In this relation, being a subset of the Muslim ummah, a Muslim must realize, contemplate and finally be convinced that his all-encompassed daily activities, worships and otherwise, are by and large guided, governed and dictated by the Islamic in- junctions. Indeed, economic activities are not the exception to this rule.

Meanwhile, economics, as widely perceived, is a positive science and Islam, being a religion, is primarily normative par excellence (Anas Zarqa, 1981). Since a Muslim's economic behaviour is dictated by the Islamic injunctions, the relationship between the two is inseparable. This is, by analogy, just like the two sides of a coin where without one side, the coin is unacceptable to serve a role as a means of exchange. By the same token, the relationship between a Muslim's economic behaviour and Islamic injunctions is just like that. That is to say, the two are mutually needed and reinforcing. To put differently, a Muslim's economic behaviour is affected, inter alia, by his outlook, beliefs and religious-based moral standards, if lumped together are known as religious 
variables. A change in any of these variables will inevitably have far-reaching economic repercussion.

Before we indulge further into describing the methods employed to establish the relationship, perhaps, we may have to deal with the following "question begging question" questions. They are: first, does relationship between religiosity and economic activities really exist? Second, if yes, is the relationship measurable? Third, again if the answer is in the affirmative order, how can that be measured and what sort of technique(s) should be employed?; fourth, would the results and findings obtain reliable?; and, finally, can they be of any use for policy formulation? What follows are the answers to the counter-factual questions.

Conceptually, the first question can be addressed by taking into account the fact that an Islamic man or Islamicus as opposed to economicus, by virtue of the divine provisions has the tendency to be more cautious in his economic dealings. This is particularly true in the case of saving ${ }^{1}$, one of many economic activities. As enshrined in the Holy Qur'an, Islam encourages its followers to spend modestly. ${ }^{2}$ Implicitly in the teaching of the quoted verse is that Muslims are advocated to save. Subject to further investigation, it is postulated in this study that due to the "constrained" consumption basket, which is firmly embedded in the notion of permissibility (halal) and prohibition (haram), Muslims are conjectured to have higher saving potential. However, as Muslims them selves have different levels of taqwa ${ }^{3}$, the way they perceive, internalise and translate the two notions of halal and haram into their

\footnotetext{
1 Saving is one of many economic activities that men are expected to directly get involved in their life. Saving is also the main focus of the present paper, henceforth, will be subject to further scrutiny.

2 See, for example, al-Qur'an, 17: 29.

3 Levels of taqwa, piety, religiosity and Islamicity in this paper are used interchangeably.
}

practical life may naturally be different. This will then have indicative impact on their saving behaviour. In this sense, it is the conviction of this paper that there exist an intimate relationship between religiosity and saving. This, perhaps, answered the first fundamental question.

To deal with the second and third questions, it should be re-emphasised here that saving essentially depends on taqwa and other economic determinants, notably consumption and income. Since the last two determinants (the well-known variables) are neatly tied to saving, and they are measurable, it is only the former variable $(\text { taqwa })^{4}$ that needs detail explanations. At this juncture, it is worth mentioning that both the Islamic and conventional techniques of measuring the degree of respondents' taqwa will be employed. The Islamic way of measuring the taqwa of a Muslim ${ }^{5}$ is the three worship representations deduced from Hadith, namely fard (obligatory), haram (prohibition), and sunnah (recommendable or praiseworthy). By contrasting the worship representations against the pillars of Islam and Iman (five and six, respectively), and employing the Renzetti and Curran (1998) fivedimension ${ }^{6}$ religiosity measurement, the respondents' degree of taqwa (religiosity) are measured. The detail explanation of the

\footnotetext{
4 We must admit without any reservation whatsoever that it is only Allah that knows best the degree of one's taqwa. What we intend to do here is to measure taqwa (religiosity) based on the exterior conviction of the respondents.

5 The questionnaire is designed in such a way that it accommodates only Muslim ritual behaviour. All respondents who participated in our study are Muslims.

6 They are: (i) ritualistic dimension; (ii) experiential dimension-how important religion in one's life; (iii) ideological dimension-how committed a person is to the religious doctrine or teachings; (iv) consequential dimension - the extent to which religion affects the way a person conducts his or her daily life; and (v) intellectual dimension - the knowledgeability of a person towards the history and teachings of a religion.
} 
techniques employed is deferred to the subsequent section. From the above discussions, the second and third fundamental questions are answered.

Next, to the question of the reliability of the study's results and finding we have to humbly submit that like any other studies conducted with human perception, experience and conviction are the elements involved, it is always the case that some unavoidable shortcomings such as sample size, content and coverage of the questionnaire and the methodology, etc are foresighted. In this respect, it is no exception as far as a study like ours, which involves religiosity, is concerned. We however believe that the statistical tools such as the correlation and regression analyzes employed in the paper will be of great assistance in enhancing the degree of reliability, albeit far from sufficient, of the study.

Hence, if this is acceptable, it goes without saying that the results and findings of the study are useful for policy formulation. With this, the fifth question is answered.

The paper is organized as follows. In section 2 , the theoretical framework is outlined. While section 3 explains the model specification, section 4 discusses the results and findings of the study. Finally, in section 5 some policy implications are outlined.

\section{THEORETICAL FRAMEWORK}

As mentioned earlier, all deeds, as long as they are performed within the shari'ah precincts, are considered as ibadah. Included in these deeds are saving and consumption where the motivation to perform them differs from one individual to another. Money that is saved out of the amount (or percentage) of income received is spent (consumed) for numerous reasons; performing hajj, getting married, starting business, emergency and many more. It will be intriguing to try to investigate whether or not the amount of money saved for the reasons cited above are deeply rooted in one's degree of piety, level of income and pattern of consumption. In general, which many Qur'anic verses and Hadith of the prophet Muhammad (saw) have shown, a Muslim saving behaviour is largely influenced by his level of religiosity. Prophet Muhammad (saw) had once said: "keep some of your properties for yourself because, it is better for you". 7 The Hadith implies that only those who are pious will take heed of the Prophet (saw) remainder, i.e., to save a fraction of one's income or property. In fact, Prophet (saw) himself used to purchase dates from Bani Nadhir and saved for his family a full year's provisions. ${ }^{8}$ In short, we can safely deduce that Islamic norms and values are the source of inspirations, which guide and influence Muslims to procure a high level of savings in his life.

Further, the level of income and the pattern of consumption are the well-known factors, which significantly influenced man's saving behaviour. Hence, given the fact that what is not consumed out of the income received will be consumed, and combined with the fact that the Muslims' consumption baskets are more constrained than the nonMuslim, the former's consumption behaviour would have a direct effect on their saving behaviour. That is to say, the Muslim, theoretically, saved more than the non-Muslim.

It is from these persuasions we hypothesize that the variabilities in the religiosity, consumption and income of the Muslims would have significant impact (or relation) on their saving behaviour. Hitherto, to the best of our knowledge, there have been no empirical studies conducted to investigate the relationship between saving and income, consumption and religiosity. This small piece of work is geared towards bridging this gap and enriching the knowledge on this subject.

\footnotetext{
7 A Hadith narrated by Bukhari.

8 Ibid.
} 


\section{MODEL SPECIFICATIONS}

As shown by al-Haq (1993), Muslims' consumption and saving behaviours are predominantly determined by both economic considerations (income and consumption) and religious teachings (religiosity). Following this line of analysis but with different method and objective, ${ }^{9}$ it is noteworthy to incorporate the two respective factors, treated as explanatory variables in this study, to the designated saving function. Specifically, while saving is treated as dependent variable, religiosity, consumption and income are treated as independent variables. Each of the specified variables is explained in greater detail below.

\section{Saving}

Unlike Sadeq (1992) and Jalaluddin (1992) where saving is qualitatively defined as income minus expenditures on consumption and spending in the way of Allah ( $f a-$ $l a h)$, in this paper it is numerically defined as income minus expenditures on consumption (e.g. clothing, food and rental) and spending in the way of Allah (e.g. zakah, sadaqah, and waqf). Defined in the latter way, saving is a function of religiosity (as reflected in the consumption behaviour where spending for Allah's sake is considered as part of saving), income and consumption.

\section{Income}

The disposable (personal) income of the students is used as the basis to measure income. Since most of the students' incomes are from the same sources, namely the scholarships and financial loans, they are considered as International Islamic University Malaysia (IIUM) students' income.

\footnotetext{
${ }^{9}$ Basically, the objective of the paper is to investigate the relationship between saving, religiosity, income and consumption where students of IIUM are the focus of analysis.
}

\section{Consumption}

The consumption of the students only consists of the spending to satisfy their human material needs but within the shari'ah injunctions, like on beverages, clothing, rentals etc. As this paper categorises the spending for Allah's sake like paying zakat, sadaqah etc as a part of Hereafter saving (Khan, 1983), therefore this type of spending is excluded from consumption. These expenditures made by the respondents are taken as their consumption.

\section{Religiosity}

Among the four, this is the most delicate variable. It is for this reason that a more lengthy explanation is needed to clarify it. As correctly pointed out by Siti 'Adilah (1999), none is able to judge, let alone to measure, a person's religiousness except Allah, since this is a personal matter between the individual and his Lord. However, assuming that a person acts rationally (as outlined in the shari'ah), ${ }^{10}$ it would not be difficult to predict, theoretically as well as empirically, the saving behaviour of Muslims. This is because a Muslim who performs the religious duties consistently and cautiously would be more religious than those who do otherwise.

In measuring the religiosity of Muslim students of IIUM, we have decomposed the act of worship into three components. They are: fard or wajib (obligatory); haram (prohibited); and sunnah or mandub (commended). Because the position or ranking of the decomposed acts of worship is significantly different from one another, more weightage is given to the wajib than, for example, to sunnah. A detail description of the weightage is as follows.

\footnotetext{
${ }^{10}$ Precisely, in Islam, rationality implies that the rational soul, which is divinely guided, is able to overcome the animal soul, which is devilly guided.
} 


\section{Obligatory Deeds}

As far as the obligatory deeds are concerned, we have divided them into two categories, namely pillars of Islam and Iman (question 1-6), or for brevity PISIM. Points are given to questions $1,4,5$ and 6 in ascending order with -2 for not important at all to +2 for very important, while to questions 2 and 3, the points of $-5,-4,-3,-2,-1$ and +5 are given (See Appendix). The latter way of assigning points is done because the nature of questions posed to and the answer expected from the respondents are different from the former. Further, because obligatory deeds are the highest in the hierarchy of all deeds, we assigned 100 points to each item listed in the two categories of deeds. While the highest score "attainable" by a person is $+1800[(2$ points $\times 100 \times 4$ deeds $)+(5$ points $\times 100 \times 2$ deeds $)=(800)+(1000)$ ], the lowest is $-1800[(-2$ points $\times 100 \times 4$ deeds $)+(-5$ points $\times 100 \times 2$ deeds $)=(-$ $800)+(-1000)]$. More formally, the obligatory deeds are quantified using the belowwritten formula:

$$
O D_{i}=100 \sum_{j=1}^{6} \operatorname{PISIM}_{i j}
$$

where:

$$
\begin{array}{ll}
\text { OD } & =\text { Obligatory Deeds. } \\
\text { PISIM } & =\text { Pillars of Islam and Iman. } \\
\mathrm{i} & =\text { the respondents. } \\
\mathrm{j} & =\text { the number of questions involved. }
\end{array}
$$

\section{Prohibited Deeds}

Five questions have been designed to measure this category of deed. Similar to the obligatory deeds, points are given in an ascending order of -2 (not important at all) to +2 (very important) to each prohibited deeds, which comprises questions 7-11 of the questionnaire. However, only 55 points are attributed to any one of the deeds committed. Hence, the highest score attainable by a person who does not commit any prohibited acts is $+550(2$ points $\times 55 \times 5$ deeds) and the lowest is $-550(-2$ points $\times 55$ $\times 5$ deeds). Expressed more formally, the prohibited deeds or FASAD are measured using the following formula:

$$
\mathrm{PD}_{\mathbf{i}}=55 \sum_{\mathrm{k}=7}^{11} \text { FASAD }_{\mathrm{ik}}
$$

where:

PD $=$ Prohibited Deeds.

FASAD $=$ the items of the PD listed in the questionnaire.

$\mathrm{i}=$ the respondents.

$\mathrm{k}=$ the number of questions involved.

\section{Recommended Deeds}

We note in passing that any recommended or commended acts performed by a person can never replace the obligatory and prohibited deeds. They, however, can only enhance the religiosity of the person. With this in mind, and with similar scaling adopted as in (3.4.1) and (3.4.2), the formula that is used to compute the commended deeds or QUDUS is as follows:

$C D_{i}=2 \sum_{l=12}^{17} Q U D U S_{i l}$

where:

$\mathrm{CD}=$ Commended Deeds.

QUDUS $=$ the items of the CD listed in the questionnaire.

$\mathrm{i}=$ the respondents.

$l=\quad=$ the number of questions involved.

Because a score of +2 is attached to each commended deed performed and the scale ranges from 0 (not important at all) to +4 (very important) for questions $12-14$, and 0 to 5 for questions 15-17, the highest score attainable by a respondent is +54 [ $(2$ points $\times 4 \times 3$ deeds $)+(2$ points $\times 5 \times 3$ deeds $)$ ] and the lowest is 0 ( 0 points $\times 5 \times 3$ deeds).

\section{Religiosity Index}

Religiosity Index (RI) which comprises all deeds, is formulated using the following formula:

$\mathbf{R I}_{\mathrm{i}}=\left[\left(\mathrm{OD}_{\mathrm{i}}+\mathrm{PD}_{\mathrm{i}}+\mathrm{CD}_{\mathrm{i}}\right) / 2404\right] \times 100 \ldots .(4)$ 
All notations used are the same as in equations (1), (2) and (3). In other words, Religiosity Index $\left(\mathrm{RI}_{\mathrm{i}}\right)$ is defined as the sum of $\mathrm{OD}_{\mathrm{i}}, \mathrm{PD}_{\mathrm{i}}$, and $\mathrm{CD}_{\mathrm{i}}(1800+550+54=$ 2404) divided by the maximum attainable points and multiplied by 100 . Ideally, the maximum score that the most religious person can accumulate is 100. A respondent is considered as par excellence or Muttaqin if he (she) performed all the obligatory and recommended deeds and, at the same time, abstained himself (herself) from committing any wrong doings (prohibited deeds) "whole-heartedly". That is to say, he (she) scored the maximum points for each deeds 1800, 54 and 550, respectively.

The index can also be taken as a benchmark. It implies that the closer a person's (respondent's) score to the index (benchmark) the religious he (she) is, and vice versa; if the person's (respondent's) score is 0 .

\section{Empirical Application of the Model}

As has been mentioned above, the model is generally built upon the conviction that saving is a function of religiosity, which is represented by the Religiosity Index (RI), income and consumption. The function, written in the form of econometrics modelling is:

$\mathbf{S}_{\mathbf{i}}=\alpha_{0}+\alpha_{1} \mathbf{R I}_{\mathbf{i}}+\alpha_{2} \mathbf{Y}_{\mathbf{i}}+\alpha_{3} \mathbf{C}_{\mathbf{i}}+\varepsilon_{\mathbf{I} \ldots \ldots \ldots \ldots \ldots \ldots . . . . . . . .(5)}$

Where:

$\mathrm{S} \quad=$ Saving.

RI = Religiosity Index.

$\mathrm{Y} \quad=$ Income.

$$
\begin{array}{ll}
\mathrm{C} & =\text { Consumption } \\
\alpha_{0} & =\text { a constant. } \\
\alpha_{1}, \alpha_{2} \text { and } \alpha_{3}= & \text { the parameters to be estimated. } \\
\varepsilon & =\text { the error random term. } \\
\mathrm{i} & =\text { the respondents } \\
& \text { (it ranges from } 1 \text { to } 160) .
\end{array}
$$

\section{Sampling}

The survey was conducted at the International Islamic University Malaysia (IIUM). Respondents were chosen primarily from two Kulliyyahs (or Faculties), Kulliyyah of Economics and Management Sciences (KENMS) and Kulliyyah of Islamic Revealed Knowledge and Human Sciences (KIRKHS). Out of 180 survey forms distributed, 160 or $88.9 \%$ were returned.

The profiles of the respondents are shown in Table 1. Briefly, as far as the gender ratio is concerned, the sample is well represented in that it tallies with the male and female composition of the university's population (i.e., students) —30 (male): 70 (female). Another aspect of the sample that contributes to the distinctiveness of the study is the race composition. As can be seen from Table 1 , the ratio of local to international students is exactly reflecting the ratio at the university level which is 80 (locals): 20 (internationals). The same is also true in the case of the levels of study and marital status, both reflecting the true picture of the university's current status quo. All in all, in so far as the sample is concerned it is very representative. 
Table 1: The Distribution of Respondents According to their Profiles

\begin{tabular}{|c|c|c|c|c|}
\hline No. & \multicolumn{2}{|c|}{ Profiles } & No. of Respondents & $\%$ \\
\hline \multirow{3}{*}{1.} & \multirow{3}{*}{ Gender: } & Male & 55 & 34.38 \\
\hline & & Female & 105 & 65.63 \\
\hline & & Total & 160 & 100.00 \\
\hline \multirow[b]{4}{*}{2.} & \multirow[b]{4}{*}{ Age: } & $18-23 \mathrm{yrs}$ & 125 & 78.13 \\
\hline & & $24-29 \mathrm{yrs}$ & 31 & 19.38 \\
\hline & & $30-35$ yrs & 4 & 2.50 \\
\hline & & Total & 160 & 100 \\
\hline \multirow{3}{*}{3.} & \multirow{3}{*}{ Race: } & Local & 129 & 80.63 \\
\hline & & International & 31 & 19.38 \\
\hline & & Total & 160 & 100 \\
\hline \multirow[b]{5}{*}{4.} & \multirow{5}{*}{ Year of Study: } & $1 s t y r$ & 101 & 63.13 \\
\hline & & 2nd yr & 19 & 11.88 \\
\hline & & $3 \mathrm{yr}$ & 20 & 12.50 \\
\hline & & $4 \mathrm{yr}$ & 20 & 12.50 \\
\hline & & Total & 160 & 100 \\
\hline \multirow{3}{*}{5.} & \multirow{3}{*}{ Level of Study: } & Undergraduate & 133 & 83.13 \\
\hline & & Postgraduate & 27 & 16.88 \\
\hline & & Total & 160 & 100 \\
\hline \multirow{3}{*}{6.} & \multirow{3}{*}{ Marital Status: } & Single & 153 & 95.63 \\
\hline & & Married & 7 & 4.38 \\
\hline & & Total & 160 & 100 \\
\hline
\end{tabular}

\section{RESULTS AND FINDING}

Results of Respondents' Religiosity

Table 2 exhibits the overall picture of how respondents responded to the questions related to the three types of the so-called fundamental duties. To save space, however, only the ones that are either consistent with or dispersed from the expected observations will be highlighted.

First, we take a look at the "missing number of obligatory prayers" item. As can be seen from Table 2 (Column 1, Line 2), there are close to $2 \%$ of students who missed, occasionally or frequently, the entire five-time daily obligatory prayers. Another $10 \%$ missed 1-4 times the said prayers. Though this undoubtedly reflects the religiosity of IIUM students, there is a need for further enquiry made.

Second, in the category of prohibited duties (deeds), it seems that most respondents are fully aware of the fact that those five are major sinful deeds, which one must, in normal circumstances, avoid. With one being the only exception, more than $90 \%$ of them are of the opinion that it is very important for them not to commit such sins. 
Third, as expected, majority of the respondents performed minimally the recommended duties. In the case of praying and fasting, for example, approximately $75-$ $80 \%$ of them are in this category.

Finally, to enable us to have greater confidence in the reliability of respondents' answers to the questions posed to them on the fundamental duties of being a Muslim, question 18 (See Appendix: Part B) was also included in the questionnaire. In Table 2, it is categorized as "autonomous confession". Indeed, there is a consistency in this answer with the previous ones. We conclude, therefore, that the sample gathered and used for the present study is reliable.

\section{Income Sources}

As implied from Table 3, of the 160 respondents, 72 or $45 \%$ are in the income bracket of RM 300-500. They are, subject to further investigation, the ones who received the government scholarship. It is also interesting to report that eight respondents $(5 \%)$ received a monthly income of more than RM 1501. Also shown in the table are 28 respondents or $17.5 \%$ who sources their income from other means as well, perhaps from doing odd jobs on or off campus.

Meanwhile, in terms of income sufficiency, it seems that those who belonged to the "upper-level" income group (>RM 1501) are the same persons who have more than enough income. In both cases, the number of respondents is eight or $5 \%$. As appeared in the table, 26 respondents $(16.25 \%)$ are experiencing financial problems.

Table 3: The Distribution of Respondents' Income, Sources and Its Sufficiency

\begin{tabular}{|c|c|c|c|c|}
\hline No. & Variable & Income Interval & $\mathrm{N}$ & $\%$ \\
\hline \multirow{7}{*}{1.} & \multirow{7}{*}{ Total Monthly Income: } & $<$ RM300. & 50 & 31.25 \\
\hline & & RM300-500. & 72 & 45.00 \\
\hline & & RM501-1, 000. & 22 & 13.75 \\
\hline & & RM1, 001-1,500. & 8 & 5.00 \\
\hline & & RM1, 501-2,000. & 6 & 3.75 \\
\hline & & $>\mathrm{RM} 2,001$. & 2 & 1.25 \\
\hline & & Total & 160 & 100 \\
\hline \multirow{3}{*}{2.} & \multirow{3}{*}{$\begin{array}{l}\text { Having extra income in addition } \\
\text { to scholarship and parents: }\end{array}$} & Yes & 28 & 17.50 \\
\hline & & No & 132 & 82.50 \\
\hline & & Total & 160 & 100 \\
\hline \multirow{5}{*}{3.} & \multirow{5}{*}{ Income Sufficiency: } & Not sufficient & 26 & 16.25 \\
\hline & & Quite sufficient & 64 & 40.00 \\
\hline & & Sufficient & 62 & 38.75 \\
\hline & & More than sufficient & 8 & 5.00 \\
\hline & & Total & 160 & 100 \\
\hline
\end{tabular}




\section{Saving Behaviour}

Table 4: The Saving Behaviour of Respondents

\begin{tabular}{|c|c|c|c|c|}
\hline No. & Variable & Income Interval & $\mathbf{N}$ & $\%$ \\
\hline \multirow{7}{*}{1.} & \multirow{7}{*}{ Total Saving: } & $<$ RM50 & 50 & 31.25 \\
\hline & & RM51-100 & 72 & 45.00 \\
\hline & & RM101-150 & 22 & 13.75 \\
\hline & & RM151-200 & 8 & 5.00 \\
\hline & & RM201-250 & 6 & 3.75 \\
\hline & & $>$ RM251 & 2 & 1.25 \\
\hline & & Total & 160 & 100 \\
\hline \multirow{7}{*}{2.} & \multirow{7}{*}{ Total Saving (in percentage): } & $<1 \%$ & 50 & 31.25 \\
\hline & & $1-5 \%$ & 72 & 45.00 \\
\hline & & $6-15 \%$ & 22 & 13.75 \\
\hline & & $16-20 \%$ & 8 & 5.00 \\
\hline & & $21-25 \%$ & 6 & 3.75 \\
\hline & & $>25 \%$ & 2 & 1.25 \\
\hline & & Total & 160 & 100 \\
\hline \multirow{3}{*}{3.} & \multirow{3}{*}{ Paying zakah: } & Yes & 28 & 17.50 \\
\hline & & No & 132 & 82.50 \\
\hline & & Total & 160 & 100 \\
\hline \multirow{6}{*}{4.} & \multirow{6}{*}{ Starting age of Saving: } & $<8$ yrs & 54 & 33.75 \\
\hline & & 8-13 yrs & 55 & 34.38 \\
\hline & & $14-19$ yrs & 38 & 23.75 \\
\hline & & $20-25$ yrs & 11 & 6.88 \\
\hline & & 26-31 yrs & 2 & 1.25 \\
\hline & & Total & 160 & 100 \\
\hline \multirow{3}{*}{5.} & \multirow{3}{*}{ Saving because of thawab: } & Yes & 130 & 81.25 \\
\hline & & No & 30 & 18.75 \\
\hline & & Total & 160 & 100 \\
\hline \multirow{4}{*}{6.} & \multirow{4}{*}{ Continue Saving: } & Yes & 152 & 95.00 \\
\hline & & No & 0 & 0.00 \\
\hline & & Undecided & 8 & 5.00 \\
\hline & & Total & 160 & 100 \\
\hline \multirow{7}{*}{7.} & \multirow{7}{*}{ Habits of Saving1: } & Family members & 122 & 26.70 \\
\hline & & Relatives & 46 & 10.07 \\
\hline & & Friends & 54 & 11.82 \\
\hline & & Self awareness & 137 & 29.98 \\
\hline & & Religious duties & 97 & 21.23 \\
\hline & & Others... & 1 & 0.22 \\
\hline & & Total & 457 & 100 \\
\hline
\end{tabular}

Note:

${ }^{1}$ For this particular question the respondents are allowed to give more than one answers 
Saving, to recall, is the study's dependent variable. Saving of the respondents is measured and expressed in two ways; total monthly saving in absolute number, and in percentage. Because saving expressed in both terms is mutually reinforcing, a regression of each of them on Religiosity Index, income and consumption is performed.

As can be seen from Table 4, in absolute and percentage terms, saving of the respondents are pretty much consistent. To take but one example, perhaps, those who saved more than RM 201 (in absolute term) and the number is eight (5\%) are the same persons who saved more than $21 \%$ of their income. It appears from here that these are the respondents who belonged to the income bracket of RM 1501 and more, and those who indicated that they have more than sufficient income (Table 3). As to how saving of the respondents is distributed, it is detailed out as items 3-7 in Table 4 and it is self-explanatory.

\section{Saving Distribution}

Table 5 shows how saving was and/or to be exhausted by the respondents. At this juncture, it is important to note that each respondent is allowed to indicate the percentage of his (her) saving that is meant for the items listed in the table. About 70\% of them saved less than $1 \%$ of their income for hajj, married, start own business and purchase shares. About $60 \%$ of the respondents saved $1-25 \%$ of their income for emergency. Because no distinction is made between worldly and non-worldly deeds, all that they saved reflects their degree of religiosity.

Table 5: The Distribution of Respondents' Saving (in percentage)

\begin{tabular}{|c|c|c|c|c|c|c|c|c|c|c|c|c|}
\hline \multirow{2}{*}{ Item } & \multirow{2}{*}{$<1 \%$} & \multirow{2}{*}{$\%$} & \multirow{2}{*}{$1-10 \%$} & \multirow{2}{*}{$\%$} & \multirow{2}{*}{$11-25 \%$} & \multirow{2}{*}{$\%$} & \multirow{2}{*}{$26-50 \%$} & \multirow{2}{*}{$\%$} & \multirow{2}{*}{$>50 \%$} & \multirow{2}{*}{$\%$} & \multicolumn{2}{|c|}{ Total } \\
\hline & & & & & & & & & & & $\mathrm{N}$ & $\%$ \\
\hline Hajj (pilgrimage) & 92 & 70.77 & 23 & 17.69 & 12 & 9.23 & 1 & 0.77 & 2 & 1.54 & 130 & 100 \\
\hline Married & 89 & 74.79 & 21 & 17.65 & 6 & 5.04 & 2 & 1.68 & 1 & 0.84 & 119 & 100 \\
\hline Start business & 87 & 73.73 & 20 & 16.95 & 7 & 5.93 & 3 & 2.54 & 1 & 0.85 & 118 & 100 \\
\hline Emergency & 28 & 18.92 & 59 & 39.86 & 44 & 29.73 & 13 & 8.78 & 4 & 2.70 & 148 & 100 \\
\hline Purchase Shares & 82 & 69.49 & 25 & 21.19 & 8 & 6.78 & 3 & 2.54 & 0 & 0.00 & 118 & 100 \\
\hline Others, .... & 5 & 29.41 & 2 & 11.76 & 5 & 29.41 & 4 & 23.53 & 1 & 5.88 & 17 & 100 \\
\hline
\end{tabular}




\section{Consumption Distribution}

Table 6: The Distribution of Respondents' Consumption

\begin{tabular}{|c|c|c|c|c|}
\hline No. & Variable & Income Interval & $\mathrm{N}$ & $\%$ \\
\hline \multirow{7}{*}{1.} & \multirow{7}{*}{ Total Consumption: } & $<\mathrm{RM} 250$ & 66 & 41.25 \\
\hline & & RM250-450 & 61 & 38.13 \\
\hline & & RM451-950 & 20 & 12.50 \\
\hline & & RM951-1, 450 & 7 & 4.83 \\
\hline & & $\mathrm{RM} 1,451-1,950$ & 5 & 3.13 \\
\hline & & $>\mathrm{RM} 1,951$ & 1 & 0.63 \\
\hline & & Total & 160 & 100 \\
\hline \multirow{7}{*}{2.} & \multirow{7}{*}{$\begin{array}{l}\text { Total Consumption } \\
\text { (in percentage): }\end{array}$} & $<75 \%$ & 6 & 3.75 \\
\hline & & $75-79 \%$ & 5 & 3.13 \\
\hline & & $80-84 \%$ & 8 & 5.00 \\
\hline & & $85-94 \%$ & 27 & 16.88 \\
\hline & & $95-99 \%$ & 68 & 42.50 \\
\hline & & $>99 \%$ & 46 & 28.75 \\
\hline & & Total & 160 & 100 \\
\hline
\end{tabular}

It should be noted here that all figures shown in Table 6 are computed based on the standard residual method. That is, what remained as a result of a sum of income (Y) that is not saved $(\mathrm{S})$ is to be consumed $(\mathrm{C})$, or technically written as $\mathrm{C}=\mathrm{Y}-\mathrm{S}$. For example, in the bottom panel of the table it is shown that 46 respondents or $28.75 \%$ consumed more than $99.0 \%$ of their income. What this actually means: they, the same respondents, saved less than $1.0 \%$ of their income. In this particular case, the income received is all consumed. However, they are cases, about six or $3.75 \%$ of them, where out of the income received, less than $75.0 \%$ is consumed. The remaining respondents stand in between of these two groups.

\section{Religiosity Index}

The indices, namely obligatory, prohibited, and recommended and total religiosity (RI) are computed based on equations (1), (2), (3), and (4), respectively. As explained earlier, the highest achievable or attainable score that a Muslim can sustain is 100 and the lowest is $-100 .{ }^{11}$ In Table 6, each index is arranged in the order of intervals. They are 9 intervals, ranges from (1120) to (91-100).

As presented in Table 6, while more than $73 \%$ of the respondents scored the highest obligatory and prohibited indices (91-100), there were none for the recommended index. For the latter index, a great majority of them is in the intervals of (3140), (41-50) and (51-60). Specifically, there are 133 respondents who belonged to this category. Perhaps, this is the reason why the total Religiosity Index $\left(\mathrm{RI}_{\mathrm{i}}\right)$ for the highest interval is somehow small, i.e., only $71 \%$. However, by lumping together the highest two intervals, the result is exceptionally appealing.

${ }^{11}$ This is only applicable for total minimum index of obligatory and prohibited deeds. Since no penalty is given to those who disobeyed the recommended acts, therefore the total lowest Religiosity Index is greater than -100 . 
Table 7: The Religiosity Index

\begin{tabular}{|c|c|c|c|c|c|c|c|c|}
\hline & \multicolumn{2}{|c|}{$\begin{array}{c}\text { Obligatory Index } \\
\left(\mathrm{OD}_{\mathrm{i}}\right)\end{array}$} & \multicolumn{2}{c|}{$\begin{array}{c}\text { Prohibited Index } \\
\left(\mathrm{PD}_{\mathrm{i}}\right)\end{array}$} & \multicolumn{2}{c|}{$\begin{array}{c}\text { Recommended Index } \\
\left(\mathrm{CD}_{\mathrm{i}}\right)\end{array}$} & \multicolumn{2}{c|}{$\begin{array}{c}\text { Total Index } \\
\text { (Religiosity Index) } \\
\left(\mathrm{RI}_{\mathrm{i}}\right)\end{array}$} \\
\cline { 2 - 9 } & $\mathrm{N}$ & $\%$ & $\mathrm{~N}$ & $\%$ & $\mathrm{~N}$ & $\%$ & $\mathrm{~N}$ & $\%$ \\
\hline $11-20$ & 1 & 0.63 & 0.00 & 0.00 & 0 & 0.00 & 0 & 0.00 \\
\hline $21-30$ & 1 & 0.63 & 1 & 0.63 & 3 & 1.88 & 2 & 1.25 \\
\hline $31-40$ & 2 & 1.25 & 1 & 0.63 & 27 & 16.88 & 0 & 0.00 \\
\hline $41-50$ & 4 & 2.50 & 2 & 1.25 & 30 & 18.75 & 1 & 0.63 \\
\hline $51-60$ & 2 & 1.25 & 2 & 1.25 & 76 & 47.50 & 4 & 2.50 \\
\hline $61-70$ & 8 & 5.00 & 1 & 0.63 & 20 & 12.50 & 7 & 4.38 \\
\hline $71-80$ & 17 & 10.63 & 6 & 3.75 & 3 & 1.88 & 8 & 5.00 \\
\hline $81-90$ & 8 & 5.00 & 16 & 10.00 & 1 & 0.63 & 25 & 15.63 \\
\hline $91-100$ & 117 & 73.13 & 131 & 81.88 & 0 & 0.00 & 113 & 70.63 \\
\hline Total & 160 & 100 & 160 & 100 & 160 & 100 & 160 & 100 \\
\hline
\end{tabular}

\section{Regression Results}

As been mentioned elsewhere in the paper, saving which is now expressed in natural logarithm (ln) term will be twice regressed on the independent variablesReligiosity Index, consumption [decomposed into two, consumption in absolute term $\left(\mathrm{C}_{\mathrm{a}}\right)$ and consumption in percentage term $\left.\left(\mathrm{C}_{\mathrm{p}}\right)\right]$ and income. That is, first, the $\ln \mathrm{S}_{\mathrm{a}}$ (the absolute-term saving), and second, the $\ln S_{p}$ (the percentage-term saving) was regressed consecutively on the explanatory variables. Also, in the course of the exercise we did include another variable, gender (GD). This is just to check whether it has any significant influence on saving.

In stark contrast with our previous study (Naziruddin and Shabri, 2001), the $\mathrm{R}^{2}$ in the present paper is higher, implying that the specified variables were able to explain more than $50.0 \%$ of the model. This has, to some extent, enhanced the reliability of the study. With few exceptions, the coefficients of the functions are all statistically significant either at $1 \%, 5 \%$ or $10 \%$. Thus, they can be used to explain the relationship between the variables, the dependent and explanatory.

First, in the case of $\ln S_{\mathrm{a}}$, there exist, though statistically not quite significant, a relationship between saving and Religiosity Index. In terms of elasticity, an increase in the Religiosity Index of $10 \%$ will lead to an increase in saving by approximately $1.1 \%$. By the same token, an increase in income or consumption by $10 \%$ will increase saving by $13.1 \%$ but will decrease saving by $13.2 \%$ and they are statistically significant. In the former case it seems that the behaviour shown by the respondents is consistent with the general observation where any additional income received by the upper income group will be used for saving purposes. It goes without saying that the relationship between saving and consumption is always inversed.

Second, with reference to $\ln \mathrm{S}_{\mathrm{p}}$, a more conclusive observation than that of $\ln S_{a}$ can be established, and the estimated parameters of the latter model $\left(\ln S_{\mathrm{p}}\right)$ are approximately equal to the former model. 
However, while the estimated parameters for income is not statistically significant, the religiosity index is significant. As for the consumption, the estimated parameter is almost the same. Meanwhile, for the gender, the result of $\ln \mathrm{S}_{\mathrm{p}}$ shows that gender plays an important role in determining the saving behaviour of a person.

Finally, the value of the two primary diagnostic tests, namely D-W (DurbinWatson $d$ test) and J-B (Jarque-Bera test), indicate that both the $\ln \mathrm{S}_{\mathrm{a}}$ with $\mathrm{D}-\mathrm{W}=1.945$ and $\mathrm{J}-\mathrm{B}=928.88$, and $\ln \mathrm{S}_{\mathrm{p}}$ with $\mathrm{D}-\mathrm{W}=$ 1.853 and $\mathrm{J}-\mathrm{B}=16.01$ are models that have no positive and negative autocorrelation among the disturbance terms. Thus, the models can be said to have asymptotically fulfilled the normality assumption, which in turn implies that the disturbance terms are normally distributed.

To conclude, in so far as saving is concerned, religiosity, consumption, income and to some extent gender could explain the manner in which the International Islamic University Malaysia (IIUM) students allocated their sources of income. As shown in the second model $\left(\ln \mathrm{S}_{\mathrm{p}}\right)$, relative to income, religiosity was the driving force behind the saving behaviour. That is to say, the higher the religiosity one, which is implied by the Religiosity Index, the higher one has the tendency to save. By and large, our findings seem to concur with the general observation, which asserts that saving and religiosity is intimately and significantly positively related.

Table 8: The Saving, Religiosity Indices, Income and Consumption

\begin{tabular}{|c|c|c|c|c|c|c|c|}
\hline Variables & Constant & $\ln T R_{i}$ & $\ln Y$ & $\ln C_{a}$ & $\ln C_{p}$ & InGD & $\mathrm{R}^{2}$ \\
\hline $\ln S_{a}$ & $\begin{array}{c}-0.392 \\
(-0.954)\end{array}$ & $\begin{array}{c}0.110 \\
(1.190)\end{array}$ & $\begin{array}{l}1.311^{*} \\
(13.68)\end{array}$ & $\begin{array}{l}-1.317^{*} \\
(-13.92)\end{array}$ & - & $\begin{array}{l}-0.633 \\
(-1.01)\end{array}$ & $\begin{array}{c}R^{2}=0.576 \\
D-W=1.945 \\
J-B=928.88\end{array}$ \\
\hline $\ln S_{p}$ & $\begin{array}{l}1.558^{\star} \\
(3.446)\end{array}$ & $\begin{array}{c}0.156^{\star \star \star} \\
(1.599)\end{array}$ & $\begin{array}{c}0.042 \\
(0.961)\end{array}$ & - & $\begin{array}{l}-1.110^{*} \\
(-19.70)\end{array}$ & $\begin{array}{c}-0.139 * * \\
(2.088)\end{array}$ & $\begin{array}{c}R^{2}=0.735 \\
D-W=1.853 \\
J-B=16.01\end{array}$ \\
\hline
\end{tabular}

Note: The numbers in the parentheses (.) are t-statistics for testing the nullhypothesis that the coefficients are equal to zero.

*,**, and *** represent a level of significance of $1 \%, 5 \%$, and $10 \%$, respectively.

D-W and $\mathbf{J}-\mathbf{B}$ indicate the Durbin-Watson $d$ test for autocorrelation and the Jarque-Bera test for normality, respectively. 


\section{Policy Implications}

While there are many policy implications that can be extracted from the results and findings of the study, we confine ourselves to three only.

\section{Incalculation and Accentuation of Reli- gious Teachings}

Income per se, though necessary, is insufficient to ensure that the saving rate of a group of people can be increased. Any increase in income, for instance, if not followed by an enhancement in the degree of religiosity can lead one (or country) to nowhere. Thus, it is important for men and women to be constantly reminded by the religious authority, at different levels, of the significance of religion in influencing their saving behaviour.

\section{Saving Disbursement Patterns}

As shown in Section 4.2 of the paper, saving is utilized for various purposes of which for emergency is top on the list followed by hajj, start own business and married (Table 5). Subject to further investigation, this actually reflects not only the saving disbursement patterns of the students but society at large. The government, in its efforts to mobilize sources of fund, should take heed of this saving behaviour.

\section{Establishment of Islamic Based Financial Intermediaries}

In relation to Section 5.2, the establishments of Islamic-based financial institutions to cater for the different needs of saving should be made realize. An institution similar to LUTH (Lembaga Urusan Tabung Haji), which is meant for those who have the intention to perform hajj, is considered feasible to cater for the needs of those who saved for getting married.

\section{BIBLIOGRAPHY}

Abdullah Yusuf Ali. 1992. The Meaning of the Holy Qur'an, Brentwood, Maryland, USA: Amana Corporation.

Siti 'Adila Abu Bakar. 1999. "Islam Attributes in Consumer Decision-Making: An Empirical Study in Singapore", M.Ec Thesis, Kulliyyah of Economics and Management Sciences, International Islamic University Malaysia.

Al-Haq, M, Ashraf. 1993. "Consumption, Saving, Investment, Fiscal Policy and Monetary Policy", M.Ec Research Paper, Kulliyyah of Economics and Management Sciences, International Islamic University Malaysia.

Ariff, M. 1982. Monetary and Fiscal Economics of Islam, in Arif, M. (Ed), King Abdul Aziz, Jeddah: International Centre for Research in Islamic economics.

Chapra, M. Umer. 1985. Towards a Just Monetary System, Leicester, UK: The Islamic Foundation.

Froyen, Richard, T,. 1996. Macroeconomics: Theories \& Policies, $5^{\text {th }}$ Edition, United States of America: Prentice-Hall, Inc.

Iqbal, Munawar. 1985. "Moderation and Aggregate Consumption in an Islamic Economy", Journal of Research in Islamic Economy, 3(1): 45-60.

Jalaluddin, AbulKhair, M,. 1992. "Saving Behaviour in Islamic Framework", M.Ec Research Paper, Kulliyyah of Economics and Management Sciences, International Islamic University Malaysia. . 1990. "Saving and Economic Development in an Islamic Economy”, Lights on Economics, International Islamic University Malaysia, 3(1): 51-61. 
Kahf, Monzer. 1992. "Saving and Investment Function in Two-Sector Islamic Economy" in Sadeq, AbulHasan, M, (Ed). Financing Economic Development: Islamic and Mainstream Approaches”, Kuala Lumpur: Longman Malaysia.

Kamali, Mohammad Hasyim. 1989. Principles of Islamic Jurisprudence, Petaling Jaya, Kuala Lumpur: Pelanduk Publication.

Khan, Akram. 1983. Issues in Islamic Economics, Lahore: Islamic Publications Ltd.

Modigliani, Franco and Brumberg, Richard. 1954. "Utility Analysis and Consumption Function: An Interpretation of Gross Section Date", in Kurihara, Kenneth, K (Ed), Post Keynesian Economists, New Brunswick: Rudgers University Press.

Naziruddin Abdullah and M. Shabri Abd. Majid. 2001. Saving Behaviour in Islamic Framework: The Case of International Islamic University, Malaysia, paper presented at $\mathrm{Na}-$ tional Workshop on Islamic Economics, Universiti Kebanggsaan Malaysia (UKM), November 5.

Naqvi. S. N. H,. 1982. "Interest Rate and Inter-temporal Allocative Efficiency in an Islamic Economy" in Ariff, M. (Ed). Monetary and Fiscal Economics of Islam, King Abdul Aziz, Jed- dah: International Centre for $\mathrm{Re}$ search in Islamic economics.

Qardhawi, Yusuf. 1997. "Peranan Nilai dan Moral Dalam Islam", (trans.) K. H. Didin Hafidhuddin, Setiawan Budiutomo and Anwar Rofiq Shaleh Tamhid. Daurul Qiyam wal Akhlaq fil Iqtishadil Islam, Jakarta: Rabbani Press.

Renzetti, C. M and Curran, D. J,. 1998. Living Sociology, USA: Allyn \& Bacon.

Sadeq, AbulHasan, M,. 1992. "Development Finance in an Islamic Economy: Domestic Sources", in Sadeq, AbulHasan, M (Ed), Financing Economic Development: Islamic and Mainstream Approaches, Kuala Lumpur: Longman Malaysia.

-------, 1990. Economic Development in Islam, Kuala Lumpur: Pelanduk Publication.

Ul-Haq, Irfan. 1996. Economic Doctrines of Islam; A Study in the Doctrine of Islam and their Implications for Poverty, Employment and Economic Growth, USA: International Institute of Islamic Thought, 1996.

Zarqa, Anas. 1981. "Islamic Economics: An Approach to Human Welfare", in Khurshid Ahmad, (Ed), Studies in Islamic Economics, United Kingdom: International Centre for Research in Islamic Economics King Abdul Aziz University, Jeddah and the Islamic Foundation. 


\section{APPENDIX}

Questionnaire

The following factors may affect your saving behaviour in general.

Please tick ( $り$ the correct box (es) relevant to you. Only Muslim students are encouraged to answer the question.

\section{Part A: Personal Details}

\begin{tabular}{|c|l|}
\multicolumn{2}{c|}{ 1. Gender: } \\
\hline Male & \\
\hline Female & \\
\hline
\end{tabular}

\begin{tabular}{|c|c|}
\multicolumn{2}{|c|}{ 2. Age: } \\
\hline$<18$ & \\
\hline $18-23$ & \\
\hline $24-29$ & \\
\hline $30-35$ & \\
\hline$>35$ & \\
\hline
\end{tabular}

\begin{tabular}{|c|c|} 
3. Race \\
\hline Malay & \\
\hline Chinese & \\
\hline Indian & \\
\hline International & \\
\hline
\end{tabular}

4. Year of study
\begin{tabular}{|l|l|}
\hline $1^{\text {st }}$ year & \\
\hline $2^{\text {nd }}$ year & \\
\hline $3^{\text {rd }}$ year & \\
\hline $4^{\text {th }}$ year & \\
\hline
\end{tabular}

5. Level of study

\begin{tabular}{|l|l|}
\hline $\begin{array}{l}\text { Undergradu- } \\
\text { ate }\end{array}$ & \\
\hline Postgraduate & \\
\hline
\end{tabular}

\section{If you are married, please answer questions 7-10.}

6. Marital Status:

\begin{tabular}{|c|l|}
\hline Single & \\
\hline Married & \\
\hline
\end{tabular}

\section{Age of} spouse:

\begin{tabular}{|c|c|}
\hline$<18$ & \\
\hline $18-23$ & \\
\hline $24-29$ & \\
\hline $30-35$ & \\
\hline$>35$ & \\
\hline
\end{tabular}

8. Race of spouse:

\begin{tabular}{|c|c|}
\hline Malay & \\
\hline Chinese & \\
\hline Indian & \\
\hline International & \\
\hline
\end{tabular}

9. No of children:

\begin{tabular}{|c|c|}
\hline \hline 0 & \\
\hline $1-2$ & \\
\hline $3-4$ & \\
\hline $5-6$ & \\
\hline$>6$ & \\
\hline
\end{tabular}

10. Type of housing:

\begin{tabular}{|c|c|}
\hline $2-3$ room & \\
\hline $4-5$ room & \\
\hline Executive flat & \\
\hline Private housing & \\
\hline Others & \\
\hline
\end{tabular}

\section{Part B: Religiousness of Respondents}

1. How important is the shahadah—bearing witness that there is none worthy of worship except Allah (swt) and Muhammad (saw) is His Messenger?

\begin{tabular}{|c|c|}
\hline Not Important & \\
\hline Least Important & \\
\hline Quite Important & \\
\hline Important & \\
\hline Very Important & \\
\hline
\end{tabular}

1. In normal circumstances, how many times do 2 you miss your obligatory prayer (salat alwajib) a day?

\begin{tabular}{|c|c|}
\hline 5-time & \\
\hline 4-time & \\
\hline 3-time & \\
\hline 2-time & \\
\hline 1-time & \\
\hline 0-time & \\
\hline
\end{tabular}

2. In normal circumstances, during the month of Ramadan, how many days do you miss your fasting?

\begin{tabular}{|c|c|}
\hline The whole Ramadan & \\
\hline $20-26$ days & \\
\hline 13-19 days & \\
\hline 8-12 days & \\
\hline 1-7 days & \\
\hline Never miss & \\
\hline
\end{tabular}


4-14. In normal circumstances, how important are the following deeds in your opinion?

\begin{tabular}{|c|c|c|c|c|c|}
\hline & 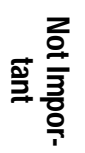 & 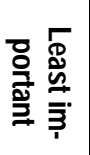 & 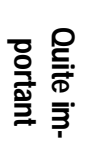 & $\begin{array}{l}\bar{\Xi} \\
\overline{8} \\
\frac{0}{2} \\
\overline{2}\end{array}$ & 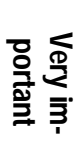 \\
\hline 4. $\quad$ Paying zakah (zakat al-mal/wealth \& zakat fitrah) & & & & & \\
\hline 5. Performing haij (pilgrimage) once you fulfilled all conditions & & & & & \\
\hline $\begin{array}{l}\text { 6. Believing in the six-pillar of Iman (belief), such as believe in } \\
\text { Allah (s.w.t), Hereafter, Angels, Divine Books, Prophets, etc. }\end{array}$ & & & & & \\
\hline 7. Not drinking liquor & & & & & \\
\hline 8. $\quad$ Not eating pork & & & & & \\
\hline $\begin{array}{l}\text { 9. Not stealing or taking other people belongings without per- } \\
\text { mission }\end{array}$ & & & & & \\
\hline 10. Not committing adultery (zina) & & & & & \\
\hline 11. Not disobey parents & & & & & \\
\hline 12. Giving donation/charity for the sake of Allah & & & & & \\
\hline 13. Spending modestly (neither extravagance nor miserliness) & & & & & \\
\hline $\begin{array}{l}\text { 14. Maintaining a good relationship (silaturrahmi) among the } \\
\text { peers, families, and neighbours. }\end{array}$ & & & & & \\
\hline
\end{tabular}

15. How many rakaats do you pray salat al-sunnah (recommended prayer) a day?

\begin{tabular}{|c|c|}
\hline None & \\
\hline $2-4$ rakaats & \\
\hline $6-10$ rakaats & \\
\hline $12-14$ rakaats & \\
\hline $16-20$ rakaats & \\
\hline$<20$ rakaats & \\
\hline
\end{tabular}

17. In a day, how many hours do you allocate your time to recite al-Qur'an?

\begin{tabular}{|c|c|}
\hline None & \\
\hline$<1$ hour & \\
\hline $1-2$ hours & \\
\hline $3-4$ hours & \\
\hline $4-5$ hours & \\
\hline$>5$ hours & \\
\hline
\end{tabular}

16. How many days do you fasting sunnah (recommended fasting) in a month?

\begin{tabular}{|c|c|}
\hline None & \\
\hline $1-3$ days & \\
\hline $3-6$ days & \\
\hline $7-11$ days & \\
\hline $12-16$ days & \\
\hline$<16$ days & \\
\hline
\end{tabular}

18. Regardless of your answer above, do you think that you are a religious person?

\begin{tabular}{|l|l|}
\hline Not religious at all & \\
\hline Least Religious & \\
\hline Quite Religious & \\
\hline Religious & \\
\hline Very Religious & \\
\hline
\end{tabular}

\section{Part C: Income of Respondents}

1. Monthly Income (it could come from your scholarship and parents).

\begin{tabular}{|l|l|l|l|l|l|}
\hline$<$ RM300 & RM300-RM500 & RM501-RM1,000 & RM1,001-RM1,500 & RM1,501-RM2,000 & $>$ RM2001 \\
\hline & & & & & \\
\hline
\end{tabular}

2. Do you have any other sources of incomes?

\begin{tabular}{|l|l|}
\hline Yes & \\
\hline No & \\
\hline
\end{tabular}


3. If yes, how much do you earn per-month?

\begin{tabular}{|l|l|l|l|l|l|}
\hline$<$ RM300 & RM301-RM500 & RM501-RM700 & RM701-RM900 & RM901-RM1000 & $>$ RM1001 \\
\hline & & & & & \\
\hline
\end{tabular}

4. Is the income generated included from part-time job? (You may tick more than one box).

\begin{tabular}{|l|l|}
\hline On Campus & \\
\hline Off campus & \\
\hline Others, please state & \\
\hline
\end{tabular}

5. In a month, how much of your income is allocated for the followings?

\begin{tabular}{|l|l|l|l|l|l|}
\hline \multicolumn{2}{|c|}{ Item } & \multicolumn{5}{c|}{ Percentage (\%) } \\
\cline { 2 - 6 } & $<1 \%$ & $1-10 \%-25 \%$ & $11-50 \%$ & $>50 \%$ \\
\hline Foods and Beverages & & & & & \\
\hline Clothing & & & & & \\
\hline Rental Housing (College) & & & & & \\
\hline Transportation & & & & & \\
\hline Books and Photocopying class materials & & & & & \\
\hline $\begin{array}{l}\text { Religious activities } \\
\text { (e.g. donation, extra-religious classes, etc) }\end{array}$ & & & & & \\
\hline Phone, Electricity, water and other Bills & & & & & \\
\hline Others, please state & & & & & \\
\hline
\end{tabular}

6. Is/Does income that you earn every month sufficient to satisfy your needs?

\begin{tabular}{|l|l|}
\hline Not sufficient & \\
\hline Quite sufficient & \\
\hline Sufficient & \\
\hline More than sufficient & \\
\hline
\end{tabular}

\section{Part D: Saving of Respondents}

1. How much do you save [including sadaqah (charity), donation, etc] per-month?

RM51-RM100

RM101-RM150

RM151-RM200

\begin{tabular}{|l|l|} 
RM201-RM250 & $>$ RM251 \\
\hline
\end{tabular}

2. Are you paying zakah, including zakat al-fitr?

\begin{tabular}{|l|l|}
\hline Yes & \\
\hline No & \\
\hline
\end{tabular}

3. If yes, how much do you pay?

\begin{tabular}{|c|c|c|c|c|c|}
\hline$<$ RM50 & RM51-RM100 & RM101-RM150 & RM151-RM200 & RM201-RM250 & $>$ RM250 \\
\hline & & & & & \\
\hline
\end{tabular}

4. Out of your total income, how many percent do you save per-month?

\begin{tabular}{|c|c|c|c|c|c|}
\hline$<1 \%$ & $1-5 \%$ & $6-15 \%$ & $16-20 \%$ & $21-25 \%$ & $>25 \%$ \\
\hline & & & & & \\
\hline
\end{tabular}


5. In a month, how much of your total income is saved for the followings?

\begin{tabular}{|l|c|c|c|c|c|}
\hline \multirow{2}{*}{ Item } & \multicolumn{5}{c|}{ Percentage (\%) } \\
\cline { 2 - 6 } & $<1 \%$ & $1-10 \%$ & $11-25 \%$ & $26-50 \%$ & $>50 \%$ \\
\hline Hajj (pilgrimage) & & & & & \\
\hline Married & & & & & \\
\hline Start your own business & & & & & \\
\hline Emergency & & & & & \\
\hline Purchase Shares & & & & & \\
\hline Others, please state & & & & & \\
\hline
\end{tabular}

6. Do you save because you are aware that any single cent saved (or contributed as sadaqah) carries thawwabwhich will be rewarded in this world and/or hereafter?

\begin{tabular}{|l|l|}
\hline Yes & \\
\hline No & \\
\hline
\end{tabular}

7. Since at the age of................you started making saving?

\begin{tabular}{|c|c|}
\hline$<8$ years & \\
\hline 8-13 years & \\
\hline $14-19$ years & \\
\hline $20-25$ years & \\
\hline $26-31$ years & \\
\hline $32-37$ years & \\
\hline$>37$ years & \\
\hline
\end{tabular}

8. What are your purposes of saving? (You may thick more than one box).

a. For future Investment:

\begin{tabular}{|l|l|}
\hline Purchase Shares & \\
\hline Performing Hajj (pilgrimage) & \\
\hline Married & \\
\hline Start own business & \\
\hline Others, please state & \\
\hline
\end{tabular}

b. For Emergency of:

\begin{tabular}{|l|l|}
\hline Yourself & \\
\hline Relatives & \\
\hline Friends & \\
\hline Nation & \\
\hline Others, please state & \\
\hline
\end{tabular}

9. If the objective of saving is achieved, will you, in future, save again?

\begin{tabular}{|l|l|}
\hline Yes & \\
\hline No & \\
\hline Undecided & \\
\hline
\end{tabular}

10. Your saving habits is developed and induced by: (You may tick more than one box).

\begin{tabular}{|l|l|}
\hline Family members & \\
\hline Relatives & \\
\hline Friends & \\
\hline Self awareness & \\
\hline Religious duties & \\
\hline Others, Please state & \\
\hline
\end{tabular}

Thank you for your co-operation 